\title{
Indian Pharmaceutical Industry: An Overview
}

\author{
Gulshan Akhtar
}

\begin{abstract}
Pharmaceutical industry contributes to the welfare of humanity and provides significant socioeconomic benefits to the society through creation of jobs, supply chains and community development. Indian Pharmaceutical industry is one of the world's largest and most developed, ranking fourth in terms of volume and thirteenth in terms of value. The country accounts for an estimated $10 \%$ of global production and $2 \%$ of world markets in pharmaceuticals. It has over the years made significant progress in infrastructure development, technical capability and hence produced a wide range of pharmaceutical products. The industry now produces bulk drugs under all major therapeutic groups. It has a sizable technically skilled manpower with prowess in process development and downstream processing. It has the capital investment of about US\$4.1billion. It produced bulk drugs of value of US\$3.5 billion and formulations worth US\$15.4billion in 2008. Bulk drugs have grown at a rate of approximately $14 \%$, and formulation by $24 \%$ in the nineties. There is an increasing interest and investment in $R \& D$. It provides employments 29 million people. The contribution of pharmaceutical sector in India's GDP is $2 \%$ and $12 \%$ of manufacturing sector GDP.
\end{abstract}

Keywords: Pharmaceutical industry; balance of trade; bulk drugs; formulation; TRIPs

\section{Introduction}

Health is defined both as cause and effect of economic development, and the pharmaceutical industry is especially recognized in the 'UN Millennium Development Goals' as an actor that can contribute to economic development. This industry is classified as one of the most high-tech and capital-intensive industries. It is considered as the 'life line' industry because its products play a crucial role in remedifying the suffering of diseased persons. It is also significant contributor to the strength of any economy by creating jobs for millions and contributing to the export earnings. The distinctive feature of this industry is such that the goods produced by this sector can neither be substituted nor replaced.

\section{Global Pharmaceutical}

The majority of global pharmaceutical sales originated in the 'Triad' (US, European Union and Japan), and together they are accounting for over $80 \%$ of the global market. The global pharmaceutical sales have grown from US\$ 334 billion in 1999 to US\$ 773 billion in 2008 and further to US\$ 776 billion in 2009 and nearly US $\$ 880$ billion in 2011 (IMS health 2009). At the regional level US, is the major pharmaceutical market accounting for around $45 \%$ of global pharmaceutical sales, followed by Europe (24\%) and Japan (11\%) (Priolker, 2009). As per IMS health Inc. the highest regional global pharmaceutical sales was in North America with 40.3\% share in the year 2008 followed by Europe (32\%) Asia, Africa and Australia (11.8\%) (Table 1).

Table-1: Global Pharmaceutical Sales by Region (2006-08)

\begin{tabular}{|c|l|c|c|c|c|c|c|}
\hline \multirow{2}{*}{ No. } & \multirow{2}{*}{ Region } & \multicolumn{3}{|c|}{ Sales US\$ Billion } & \multicolumn{3}{c|}{ Market Share (\%) } \\
\cline { 3 - 8 } & & 2006 & 2007 & 2008 & 2006 & 2007 & 2008 \\
\hline 1. & North America & 289.9 & 304.5 & 3118 & 47.7 & 45.9 & 40.3 \\
\hline 2. & Europe & 181.8 & 206.2 & 247.5 & 29.9 & 31.1 & 32.0 \\
\hline 3. & $\begin{array}{l}\text { Asia, Africa \& } \\
\text { Australia }\end{array}$ & 52.0 & 62.2 & 90.8 & 8.6 & 9.4 & 11.8 \\
\hline 4. & Japan & 56.7 & 58.5 & 76.6 & 9.3 & 8.8 & 9.9 \\
\hline 5. & Latin America & 27.5 & 32.0 & 46.5 & 4.5 & 4.8 & 6.0 \\
\hline \multicolumn{2}{|c|}{ Total } & 607.9 & 663.5 & 773.1 & 100.0 & 100.0 & 100.0 \\
\hline
\end{tabular}

Note: Ranked by 2008 Global sales

Source: IMS Health Inc. 


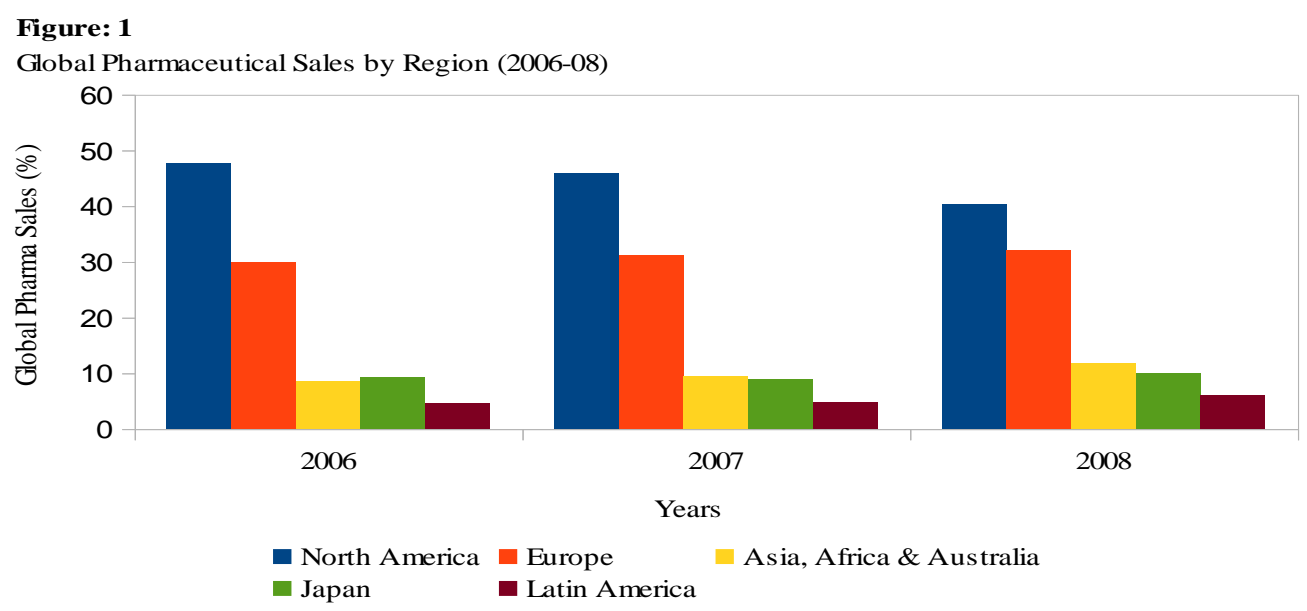

The share of pharmaceutical products in world exports has grown over the years. It was $1.7 \%$ in 2000 which has increased to $2.6 \%$ in 2005 (Exim Bank, 2007). European Union as a bloc was the largest exporter of it and accounted for $68.7 \%$ of total global pharmaceutical exports in 2008 followed by Switzerland (10.4\%), USA $(9.0 \%)$, China $(1.9 \%)$ and others. India occupies $6^{\text {th }}$ position $(1.4 \%)$. Together their shares stood at $96.8 \%$ of global pharmaceutical exports (Table 2).

Table-2: Major Exporters of Pharmaceutical Products in the World (2008).

\begin{tabular}{|l|c|c|}
\hline \multicolumn{1}{|c|}{ Exporters } & Value (US\$ Billions) & \% Share \\
\hline European Union (27)* & 293.3 & 68.7 \\
\hline Switzerland & 44.2 & 10.4 \\
\hline USA & 38.3 & 9.0 \\
\hline China & 8.1 & 1.9 \\
\hline Canada & 6.2 & 1.4 \\
\hline India & 5.8 & 1.4 \\
\hline Singapore & 5.0 & 1.2 \\
\hline Israel & 4.8 & 1.1 \\
\hline Jordan & 3.7 & 0.9 \\
\hline Australia & 3.3 & 0.8 \\
\hline Total & 412.7 & 96.8 \\
\hline
\end{tabular}

Note: * refers to 27 number of member countries of EU.

Source: compiled from International Trade Statistics, 2009. World Trade Organization

Figure: 2

Major Exporters of Pharmaceutical Products in the World (2008)

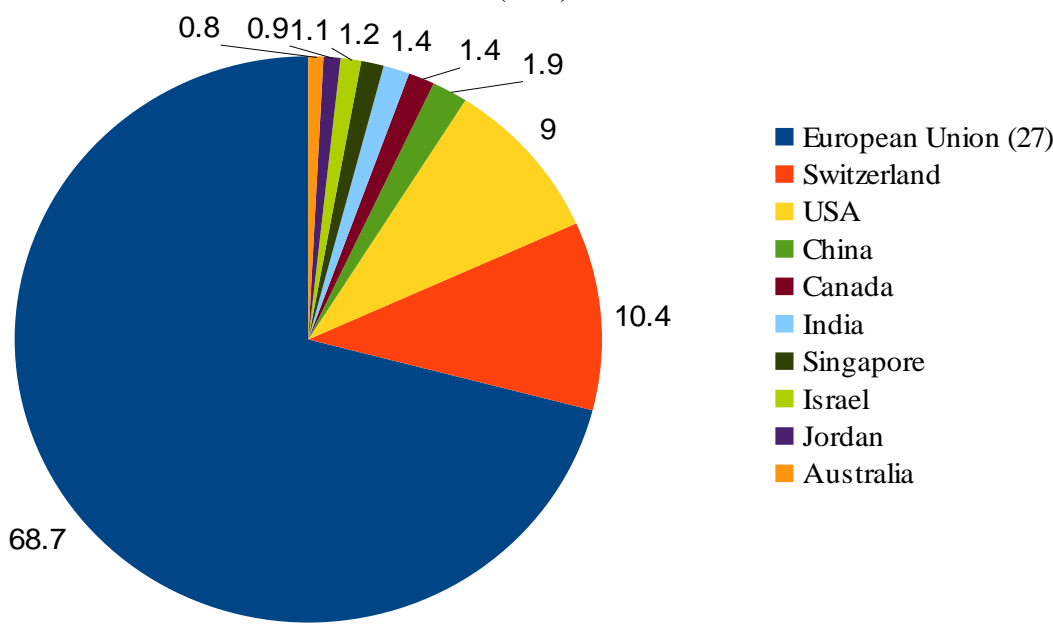

European Union as a bloc was also the largest importer of pharmaceutical products. In the year 2008 they imported $56.4 \%$ of world pharmaceutical imports followed by USA (14\%), Switzerland (4.2\%), Japan $(2.7 \%)$ and others. Together their shares stood at $87.4 \%$ of world pharmaceutical imports (Table 3 ). 
Table-3: Major Importers of Pharmaceutical Products in the World (2008)

Note: * refers to 27 number of member countries of EU.

\begin{tabular}{|l|c|c|}
\hline \multicolumn{1}{|c|}{ Imports } & Value (US\$ Billions) & \% Share \\
\hline European Union (27)* & 240.5 & 56.4 \\
\hline USA & 59.9 & 14.0 \\
\hline Switzerland & 17.8 & 4.2 \\
\hline Japan & 11.4 & 2.7 \\
\hline Canada & 11.0 & 2.6 \\
\hline Russian Federation & 9.2 & 2.2 \\
\hline Australia & 7.1 & 1.7 \\
\hline China & 5.5 & 1.3 \\
\hline Brazil & 5.0 & 1.2 \\
\hline Turkey & 4.7 & 1.1 \\
\hline Total & 372.1 & 87.4 \\
\hline
\end{tabular}

Source: compiled from International Trade Statistics, 2009. World Trade Organization

Figure: 3

Major Importers of Pharmaceutical Products in the World (2008)

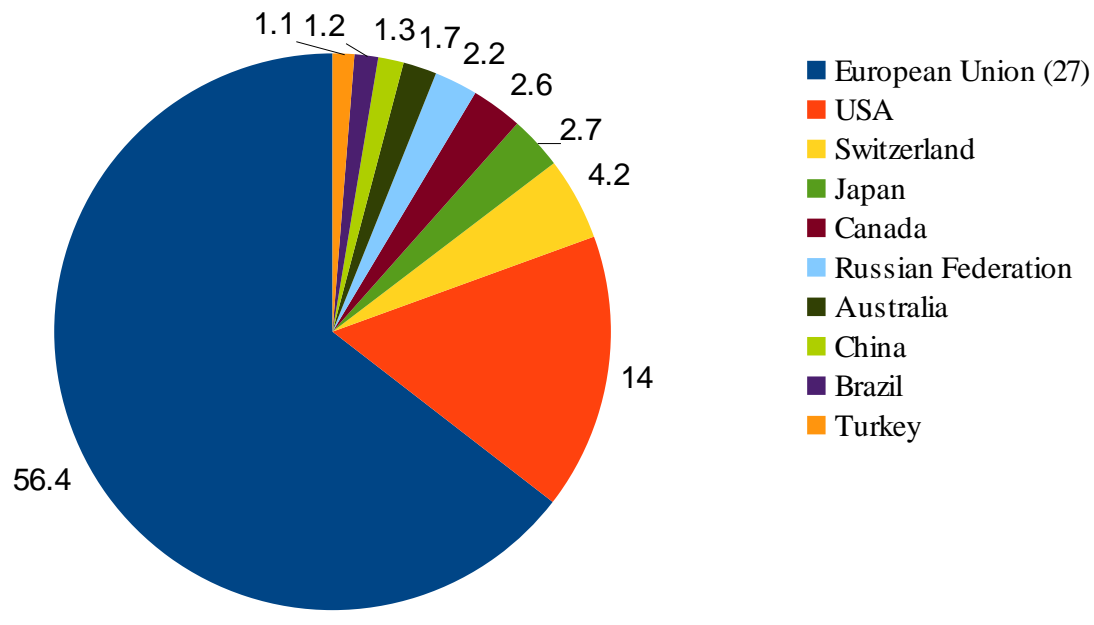

III. Indian Pharmaceutical Industry:

The history of modern Indian pharmaceutical industry (IPI) dates back to the early twentieth century, when increased nationalism gave rise to greater interest in science, including pharmaceuticals. The foundation to two firms, which are still in existence today, marks the start of the modern pharmaceutical industry. One is Bengal Chemical and Pharmaceutical Work (BCPW) Ltd. set up in Kolkata by Acharya PC Ray in 1901. The other is Alembic Chemical Works Co. Ltd. in Vadodara by TK Grajjar,Rajmitra and BD Amin in 1907. Both the companies began an important shift from traditional methods to a more scientific approach to the discovery, development and manufacture of pharmaceuticals. At the early stage of development, Indian pharmaceutical companies relied heavily on foreign companies for their bulk drug requirements. The development of the IPI can be divided into three phases:

1) Indian Pharmaceutical Industry from 1900 to 1970.

2) Indian Pharmaceutical Industry from 1970 to 1990.

3) Indian Pharmaceutical Industry after 1995: Post TRIPs Period. The evaluation of IPI can be shown in the following chart (chart-1). 


\section{Chart-1: Evaluation of Indian Pharmaceutical Industry}

\begin{tabular}{|c|c|c|c|c|}
\hline $\begin{array}{l}\text { Phase I Early Years } \\
\text { - Market share } \\
\text { domination by } \\
\text { foreign } \\
\text { companies } \\
\text { - Relative } \\
\text { absence of } \\
\text { Indian } \\
\text { companies }\end{array}$ & $\begin{array}{l}\text { Phase II Govemment } \\
\text { Control } \\
\text { - Indian Patent } \\
\text { Act } 1970 \\
\text { - Drug Price } \\
\text { Capped } \\
\text { - Local } \\
\text { Companies } \\
\text { beginto } \\
\text { make an } \\
\text { impact }\end{array}$ & $\begin{array}{l}\text { - Process } \\
\text { Development } \\
\text { Phase III Development } \\
\text { Phase } \\
\text { Infrastructure } \\
\text { Creation } \\
\text { - Export Initiative }\end{array}$ & $\begin{array}{l}\text { Phase IV Growth Phase } \\
\text { - Rapid Expansion } \\
\text { of Domestic } \\
\text { Market } \\
\text { Development } \\
\text { - Research } \\
\text { Orientation }\end{array}$ & $\begin{array}{l}\text { Phase V Innovation and } \\
\text { Research } \\
\text { - New Intellectual } \\
\text { Property Law } \\
\text { - Discovery Research } \\
\text { - Convergence }\end{array}$ \\
\hline 1970 & 1980 & 1990 & 2000 & 2010 \\
\hline
\end{tabular}

The government of India is striving hard to put pharmaceutical industry on the sound track of growth and development from late 1980s. Pharmaceutical industry in India is flourishing at an accelerated rate and it is assumed that soon India will be a global pharma super power and flagship bearer in global pharmaceutical industry.

The Government of India has taken some strategic policy (including fiscal and EXIM) changes to move in that direction, which are briefly described as follows: (NPP, 2006).

- The earlier policy of procuring industrial licensing for all kind of drugs has been abolished (it has recently been done for the last remaining bulk drugs produced by the use of recombinant DNA technology, bulk drugs requiring in-vivo use of nucleic acids and specific cell tissue targeted formulations). However, the need for obtaining manufacturing license under drugs and cosmetics Act, 1940 continues for all units, whether organized or small scale. The state drug controllers are authorized to issue such licenses in most cases.

- Now, FDI upto $100 \%$ is permitted, subject to stipulations laid down from time to time in the industrial policy through the automatic route in the case of all bulk drugs cleared by the drug controller general India (DCGI) and their intermediates and formulation. Recently bulk drugs produced by the use of recombinant DNA technology, bulk drugs requiring in-vivo use of nucleic acid as the active principles and special cell/tissues targeted formulation have also been allowed this facility. Besides $100 \%$ EOUs and units of EPZs enjoy a package of incentives and facilities, which include duty free imports of all type of capital goods, raw materials and consumables in addition to tax holidays against export.

- As recommended by Mashelkar Committee in 1999, a Pharmaceutical Research and Development Support Fund (PRDSF) with a corpus of Rs.150 crores have been set up under the administrative control of the Department of Science and Technology. A Drug Development Promotion Board (DDPB) to administer the utilization of PRDSF has also been set up.

- Product patent in pharmaceuticals has been introduced in the country, with effect from January 1, 2005 by amending the patent Act 1970 in conformity with TRIPs agreement.

- $\quad$ VAT has been introduced in India with effect from $1^{\text {st }}$ April 2005 and on medicines it has been kept at $4 \%$.

- In union budget 2008-09 finance minister P. Chidambaram brought down excise duty from 16\% to 8\% and zero excise duty on anti AIDS drugs. Besides $125 \%$ weighted deduction granted on expenditure for out sourced R\&D exemption of excise duty and $5 \%$ reduction in custom duty on certain specific life saving drugs and bulk drugs used in the manufacture of Anti-AIDS drugs is allowed. This augurs well for the 
industry. Besides this the rate of CST reduced from $3 \%$ to $2 \%$ from $1^{\text {st }}$ April 2008 and reduction in the general rate of CENVAT from $16 \%$ to $14 \%$ on medicines. In 2008-09 further reduced the excise duty across the board by $4 \%$. This effectively meant reduction from $8 \%$ to $4 \%$ on formulation and $14 \%$ to $10 \%$ on bulk drugs. Whereas specific reduction in taxes for pharmaceutical goods will lead to a balanced industrial development in the pharmaceutical sector where there was lopsided development in tax havens like Himachal Pradesh, Sikkim and Uttaranchal (express pharma 2008).

\section{Trends In Production Of Indian Pharmaceutical Industry.}

The Indian pharmaceutical sector is a heterogeneous mixture of both organized and unorganized firms. They range from large firms that are either subsidiaries of MNCs or wholly Indian companies to medium and small sized companies. As per directory of pharmaceutical manufacturing units in India (2007), there are 10563 pharmaceutical manufacturers across the country, as against the commonly quoted figure of 23,000 manufacturing units. Out of these 10563 units, 8174 (77.4\%) manufacturing formulation and remaining 2389 $(22.6 \%)$ are engaged in manufacturing of bulk drugs. Pharmaceutical industry in Indian is highly fragmented, having about 300 units in the organized sector including $45 \mathrm{MNCs}$ and 5 public sector enterprises. These firms account for $70 \%$ of India's total production of pharmaceuticals.

Similarly the IPI are very unevenly distributed according to their manufacturing units. As per Mashelkar Committee (2003) more than 75\% drug manufacturing licenses are in 7 states namely, Maharashtra, Gujarat, Tamil Nadu, Andhra Pradesh, Karnataka, West Bengal and Goa, whereas 10 states namely Bihar, Delhi, Haryana, Kerala, Madhya Pradesh, Orissa, Punjab, Rajasthan, Andaman \& Nicobar, Island and Uttar Pradesh account for $20 \%$ of drug manufacturing units. The remaining 18 states and union territories have only $5 \%$ of manufacturing plants. The chief reason for this regional pharmaceutical imbalance is that almost all of the total 22 pharmaceutical \& biotech SEZs are located in the states Andhra Pradesh, Maharashtra, Gujarat and Karnataka (Express pharma, 2007).

The process of drug manufacturing has two interlinked components (a) bulk drugs (b) formulation. The domestic formulation market can be further classified into: (i) retail and (ii) institutional drug market. In India institutional drug market is quite limited accounting only $15 \%$ of total formulations sales (IBEF, 2008). The bulk drug industry closely resembles a perfectly competitive market; there is large number of players in almost all the bulk drugs markets with none enjoying market dominance. But the formulation market in India as elsewhere in the world is dominated by the large companies. Additionally the IPI manufacture close to 500 bulk drugs belonging to several therapeutic segments such as anti-infective, pain management, cardiovascular (CVS), Central Nervous System (CNS) and anti-diabetics and formulation is made for around 60,000 packs in 60 therapeutic categories are made (Jha, 2007). Although formulations account for a large share of the overall pharmaceutical production in value terms the proportionate share of bulk drugs has been increasing. Since the mid 1990s Indian's strong base in the chemical industry facilitated the development of bulk drug manufacture reverse engineering and competitiveness contribute. It is important to note that during 2005-06 to 2008-09 the growth rate of bulk drugs production was nearly half (14\%) as compared to the growth rate of formulation production (24\%).

Bulk drugs began to be produced in the country on a large scale from 1970 onwards. The most rapid growth of both bulk drugs and formulation has taken place from the 1990s onwards. As a result production of bulk drugs sharply increased from US\$417.1 million in 1990-91 to US\$3503.2 million in 2008-09. Currently, India is the third largest bulk drugs producer after China and Italy and will expect to be the second largest after China in future (Express Pharma, 2010). Similarly formulation production increased from US\$2194.3 million to US\$15390.8 million over the same years (Table 4). Growth rate of the production of bulk drugs revealed the same increasing trends since 1998. Whereas formulation shown fluctuating trends which was highest in 2007 $(32 \%)$.

Table-4: Production of Bulk Drugs and Formulation at Current Prices in India (1990-2008).

\begin{tabular}{|l|c|c|c|c|c|c|}
\hline Year & $\begin{array}{c}\text { Bulk Drug } \\
\text { Production }\end{array}$ & $\begin{array}{c}\text { Growth } \\
\text { Rate }\end{array}$ & $\begin{array}{c}\text { Formulation } \\
\text { Production }\end{array}$ & $\begin{array}{c}\text { Growth } \\
\text { Rate } \\
\text { Production } \\
\text { \#\# }\end{array}$ & $\begin{array}{c}\text { Growth } \\
\text { Rate }\end{array}$ \\
\hline $1990-91$ & 417.1 & - & 2194.3 & - & NA & - \\
\hline $1991-92$ & 396.5 & -4.9 & 2114.5 & -3.6 & 2510.6 & - \\
\hline $1992-93$ & 444.0 & 12.0 & 2316.6 & 9.6 & 2760.6 & 10.0 \\
\hline $1993-94$ & 420.4 & -5.3 & 2197.5 & -5.1 & 2617.8 & -5.2 \\
\hline $1994-95$ & 483.4 & 15.0 & 2527.1 & 15.0 & 3010.5 & 15.0 \\
\hline $1995-96$ & 562.3 & 16.3 & 2816.4 & 11.4 & 3810.7 & 26.6 \\
\hline
\end{tabular}




\begin{tabular}{|c|c|c|c|c|c|c|}
$1996-97$ & 617.5 & 9.8 & 2964.4 & 5.3 & 4286.8 & 12.5 \\
\hline $1997-98$ & 722.6 & 17.0 & 3324.5 & 12.1 & 4677.4 & 9.1 \\
\hline $1998-99$ & 762.2 & 5.5 & 3360.3 & 1.1 & 4560.0 & -2.5 \\
\hline $1999-00$ & 876.3 & 15.0 & 3703.0 & 10.2 & 5086.4 & 11.5 \\
\hline $2000-01$ & 1009.6 & 15.2 & 4087.8 & 10.4 & 5655.2 & 11.2 \\
\hline $2001-02$ & 1152.3 & 14.1 & 4471.2 & 9.4 & 5761.7 & 1.9 \\
\hline $2002-03$ & 1343.4 & 16.6 & 4976.3 & 11.3 & 6317.2 & 9.6 \\
\hline $2003-04$ & 1658.6 & 23.5 & 5942.5 & 19.4 & 7665.3 & 21.3 \\
\hline $2004-05$ & 1994.3 & 20.2 & 7052.1 & 18.7 & 9295.5 & 21.3 \\
\hline $2005-06$ & NA & - & NA & - & 10390.2 & 11.8 \\
\hline $2006-07$ & 2676.6 & - & 10072 & - & 11922.3 & 14.7 \\
\hline $2007-08^{\#}$ & 3346.7 & 25.0 & 13256.9 & 31.6 & 15734.6 & 32.0 \\
\hline $2008-09^{\#}$ & 3503.2 & 4.7 & 15390.8 & 16.1 & 17567.6 & 11.6 \\
\hline
\end{tabular}

Note: During 1990 to 1994 figures do not includes production from unorganized sector which is estimated at an additional $35 \%$ of the production.

NA: refers to not available,

\#: Estimated value.

\#\#: Total production included bulk drug production, formulation production and over-the-counter production

Source: Compiled from Bulk Drug manufacturer associationHyderabadand Indian drug manufacturer associationMumbai, data bank. RBI Handbook of statistics on Indian economy, 2009 Economic Survey 200809, Govt. of India, and CMIE “Industry market size and shares (various years).

Figure: 4

Production of Bulk Drugs and Formulation (1990-2008)

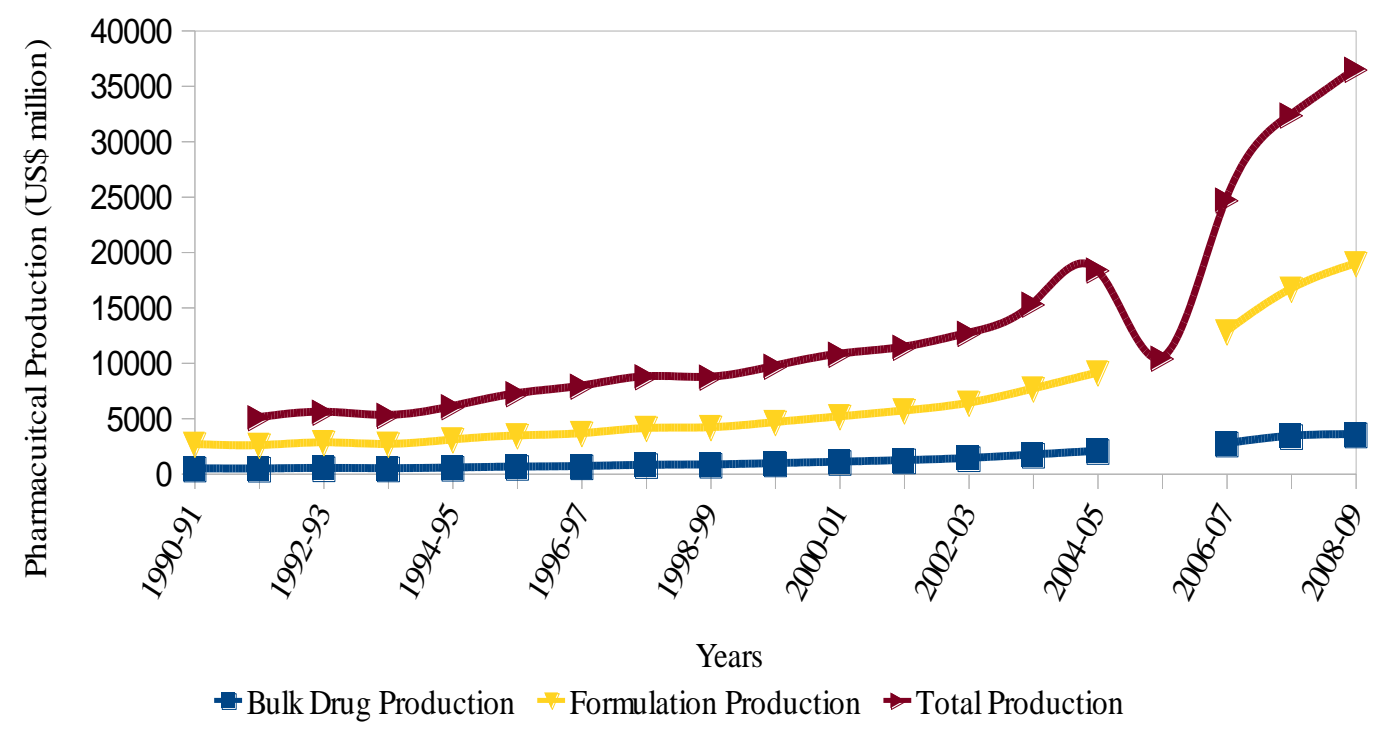

India also enjoyed trade surplus since 1987-88, and it has increased to US\$14.3 million in the year 1988 to US\$215.6 million in 1990 and further US\$4.3 billion in 2008-09. It was expected that India's exports will show strong growth in future through US\$60 billion patented drugs lost their patent protection in the US and Western Europe. ASSOCHAM predicts that Indian companies will capture at least 30\% of the replacement market of generic drugs. One of the basic reasons for this dramatic exports expansion seems to be the efforts of Indian pharmaceutical companies to develop their own marketing and trade supporting centers in the developed countries and emergence of generic segments as cheaper alternatives to branded products. Most of the Indian firms have built their own brand-names and formulations in developed countries market and are known for their internationally certified manufacturing facilities for quality and safety. Apart from these advantages, Indian firms are also leveraging benefits from forging strategic and marketing alliance with local firms in the destination markets. As far as CAGR of pharmaceutical exports are concerned, it is 16\% during 1991 to 2008. 
Similarly the CAGR of imports and balance of trade are $11.6 \%$ and $20.1 \%$ respectively over the same period of time.

Exports constitute a substantial part of the total production with $15 \%$ CACR, while the domestic market grows at 5\%. The formulations constitute nearly $55 \%$ of the total exports and the rest $45 \%$ comes from bulk drugs. Currently there are around 3000 registered exporters of which 1500 are active exporters in India. Maharashtra leads in pharmaceutical exports with a share of 38\% followed by Andhra Pradesh, Haryana, Gujarat, Karnataka, Tamil Nadu, Delhi, and Chandigarh with the shares of 23\%, $8 \%, 8 \%, 6 \%, 4 \%, 3 \%$ and $2 \%$ respectively (Pharmaxil, 2009).

Pharmaceutical as a percent of India's total manufactured exports has shown fluctuating trend during 1991 to 2008 , this currently stands in $4.7 \%$. Shares of Indian pharmaceutical export in world pharmaceutical export had also shown the increasing trend.

India's pharmaceuticals export is to more than 200 countries. On a country wise basis the top five destinations of India's pharmaceutical products during 2007-08 are the USA (19\%), Germany (4.7\%), Russia (4\%), U.K. (3.7\%) and China (2.8\%). All the major Indian pharmaceutical companies are looking at the global market to accelerate their growth performance. These include such potential regulated markets as the US, Japan and Europe, the semi regulated markets of BRICS (Brazil, Russia, India China and South Africa) countries and least regulated markets of Africa, middle east and South East Asia. India has become a very important source of generic drugs for the developing countries and one of the leading suppliers of cheapest AIDS drugs to the world. India's largest single export market continues to be the US, which is also the world largest generic drug market. Pharmaceutical exports to US grew from US\$53.9 million in 1991-92 to \$1546.9 million in 2008. But, as a percentage of total exports to the US declined slightly from $17.1 \%$ in the year 2002 to $14.3 \%$ in 2005 . This decline can be attributed to, such factors as introduction of authorized generic drugs by domestic US pharmaceutical giants, lagging profits and declining generic drug prices and growing competition from other low cost countries, particularly Israel, China, Korea and those from East Europe. (Gregory Roumeliotes, 2006). India's top ten export destinations are USA, Germany, Russia, UK, China, Brazil, Canada, Italy, Singapore and Japan which together accounted for about $60 \%$ of total Indian pharmaceutical exports in the 1991 and $37 \%$ in 2008. But now the Indian pharmaceutical exports destination have turned more towards African, South East, Asian and Other developing countries.

\section{India 'S Pharmaceutical Industry Research And Development.}

In today's world, ability to develop low cost technologies and become owner of intellectual property is one of the most important requirements for becoming leaders in knowledge based pharmaceutical industry. It is a paradox that not even a single Indian company is undertaking original technological development and R\&D. If we can combine our low cost advantage with indigenous technology, our industry could become a leading global player.

Pharmaceutical industry being one of the most technology intensive industries, R\&D investment plays a crucial role in its growth. This industry is a typical case where R\&D and profitability are closely interrelated. $\mathrm{R} \& \mathrm{D}$ in the sector includes directional research for solutions along with the existing medical requirements. Pharmaceutical R\&D may also be aimed at improving the existing solutions to improve the efficiency and safety of medicines. It can be broadly classified into three categories (1) Development of New Chemical Entries (NCEs) (2) Modifications of Existing NCEs (New chemical derivatives, new formulations, new combinations, new and modified dosages forms or Novel Drug Delivery System (3) Development of new process for manufacturing drugs (whether old or new) or generic products. Till recently, R\&D in Indian pharmaceutical companies has been primarily of the third type i.e. generic products.

An important reason why Indian companies undertake R\&D primarily for generic drugs because of new drug development is a costly, time consuming and risky business. The activities can be broadly classified into pre-clinical and clinical stages. The objective of the pre-clinical stage is to develop a promising molecule which is safe in animal testing. At the clinical stage, the molecule is tested on humans and is developed for manufacturing and marketing. The fully capitalized cost of a new drug has been estimated to be US $\$ 847$ million abroad (DiMasi et al, 2003).

However, the Indian private sector started investing in R\&D for developing new drugs since the mid 1990s when TRIPs came into effect. It was initiated by Dr. Reddy's and Ranbaxy. Thereafter, a few other companies have also joined in. At present, there are about 15 Indian pharmaceutical companies which have been set up or are in the process of setting up new research centers with NDDR as a major objective. Ranbaxy has spent the largest account US\$108.5 million in the year 2008 followed by Dr. Reddy's laboratories US\$81.3 million, Sun pharmaUS\$66 million and others (Table 5). It is indicated that in 2008-09 top ten leading 
Table-5: R\&D Expenditure of the Indian Leading Pharmaceutical Companies (1998-2008).

\begin{tabular}{|c|c|c|c|c|c|c|c|c|c|c|c|c|c|c|c|c|c|c|c|c|}
\hline \multicolumn{21}{|c|}{ US\$ millio } \\
\hline Year & Ranbaxy & \begin{tabular}{|l|} 
G.R. \\
$(\%)$ \\
\end{tabular} & \begin{tabular}{|c|} 
Dr. \\
Reddy'
\end{tabular} & \begin{tabular}{|l|} 
G.R. \\
$(\%)$ \\
\end{tabular} & \begin{tabular}{|c} 
Sun \\
Phamma
\end{tabular} & \begin{tabular}{|l|} 
G.R. \\
$(\%)$ \\
\end{tabular} & \begin{tabular}{|l|} 
Wodk- \\
hardt
\end{tabular} & \begin{tabular}{|l|} 
G.R. \\
$(\%)$ \\
\end{tabular} & Cadila & \begin{tabular}{|l|} 
G.R. \\
$\%)$ \\
\end{tabular} & Glemand & \begin{tabular}{|l|} 
G.R. \\
$(\%)$ \\
\end{tabular} & Torrent & $\begin{array}{l}\text { G.R. } \\
(\%)\end{array}$ & Cipla & \begin{tabular}{|l|} 
G.R. \\
$(\%)$
\end{tabular} & $\begin{array}{l}\text { Auro- } \\
\text { bindo }\end{array}$ & \begin{tabular}{|l|} 
G.R. \\
$(\%)$ \\
\end{tabular} & Lupin & \begin{tabular}{|l|} 
G.R. \\
$(\%)$ \\
\end{tabular} \\
\hline 1998 & 10.4 & - & 2.7 & - & 2.4 & - & 6.2 & - & 4.6 & - & 0.8 & - & 1.0 & - & 5.6 & - & 2.2 & - & NA & - \\
\hline 1999 & 12.8 & 22.6 & 3.1 & 15.9 & 4.2 & 72.5 & 8.4 & 35.5 & 4.9 & 6.3 & 1.2 & 60.7 & 2.3 & 128.2 & \begin{tabular}{|l|l|}
27.0 \\
\end{tabular} & \begin{tabular}{|l|}
25.0 \\
\end{tabular} & 3.3 & 50.0 & NA & - \\
\hline 2000 & 12.7 & -0.5 & 5.1 & 66.0 & 4.5 & 6.7 & 7.1 & $\begin{array}{c}- \\
15.1\end{array}$ & 5.6 & 12.7 & 2.3 & 88.3 & 4.5 & 92.0 & 5.1 & -26.4 & 1.8 & -46.7 & NA & - \\
\hline 01 & 16.3 & 28.5 & 10.8 & 110.9 & 5.3 & 18.9 & 6.4 & $\begin{array}{c}- \\
10.8\end{array}$ & 8.9 & 59.8 & 2.5 & 11.9 & 4.7 & 4.6 & 4.7 & $|-9.0|$ & 1.3 & -28.7 & NA & - \\
\hline 2002 & 39.5 & 142.2 & 15.2 & 40.9 & 7.0 & 32.1 & 7.0 & 10.1 & 7.8 & -12.1 & 6.4 & 150.9 & 6.4 & 36.8 & 10.7 & 129.6 & 2.9 & 126.6 & 7.8 & - \\
\hline 2003 & 59.2 & 49.9 & 30.3 & 98.7 & 20.8 & 197.5 & 12.9 & 84.0 & 18.9 & 141.5 & 7.9 & 24.5 & 8.6 & 34.6 & 12.2 & 14.3 & 4.7 & 63.9 & 10.1 & 29.5 \\
\hline 2004 & 73.1 & 23.4 & 43.9 & 45.2 & 28.0 & 34.7 & 15.3 & 18.8 & 22.7 & 20.4 & 10.8 & 35.4 & 14.9 & 73.1 & 21.7 & 77.6 & 10.8 & 129.1 & 18.5 & 82.2 \\
\hline 2005 & 110.2 & 50.8 & 57.6 & 31.1 & 32.4 & 15.7 & 18.4 & 20.2 & 27.0 & 18.7 & 10.6 & -1.5 & 19.8 & 33.4 & 35.1 & 61.8 & 12.2 & 13.2 & 24.5 & 32.7 \\
\hline 06 & 85.2 & -22.7 & 47.5 & -17.6 & 44.6 & 37.5 & 30.5 & 65.7 & 27.4 & 1.4 & 9.9 & \begin{tabular}{|l|}
-6.2 \\
\end{tabular} & 16.3 & -17.6 & 38.9 & 10.5 & 17.0 & 38.8 & 31.4 & 28.1 \\
\hline 2007 & 111.4 & 30.7 & 59.6 & 25.5 & 67.6 & 51.5 & 36.8 & 20.8 & 32.4 & 18.5 & 10.4 & 4.8 & 22.0 & 34.9 & 56.2 & 44.6 & 23.5 & 38.2 & 49.3 & 57.3 \\
\hline 2008 & 108.5 & -2.6 & 81.3 & 36.6 & 66.1 & -2.1 & 38.0 & 3.3 & 30.6 & -5.5 & 11.8 & 12.9 & 26.0 & 18.2 & 56.2 & 0.1 & 4.1 & -82.3 & 61.5 & 24.6 \\
\hline
\end{tabular}

Note: G.R. refers to Growth Rate.

NA refers to Not Available.

Source: Compiled from Annual Report (Various years) and websites of the respected companies

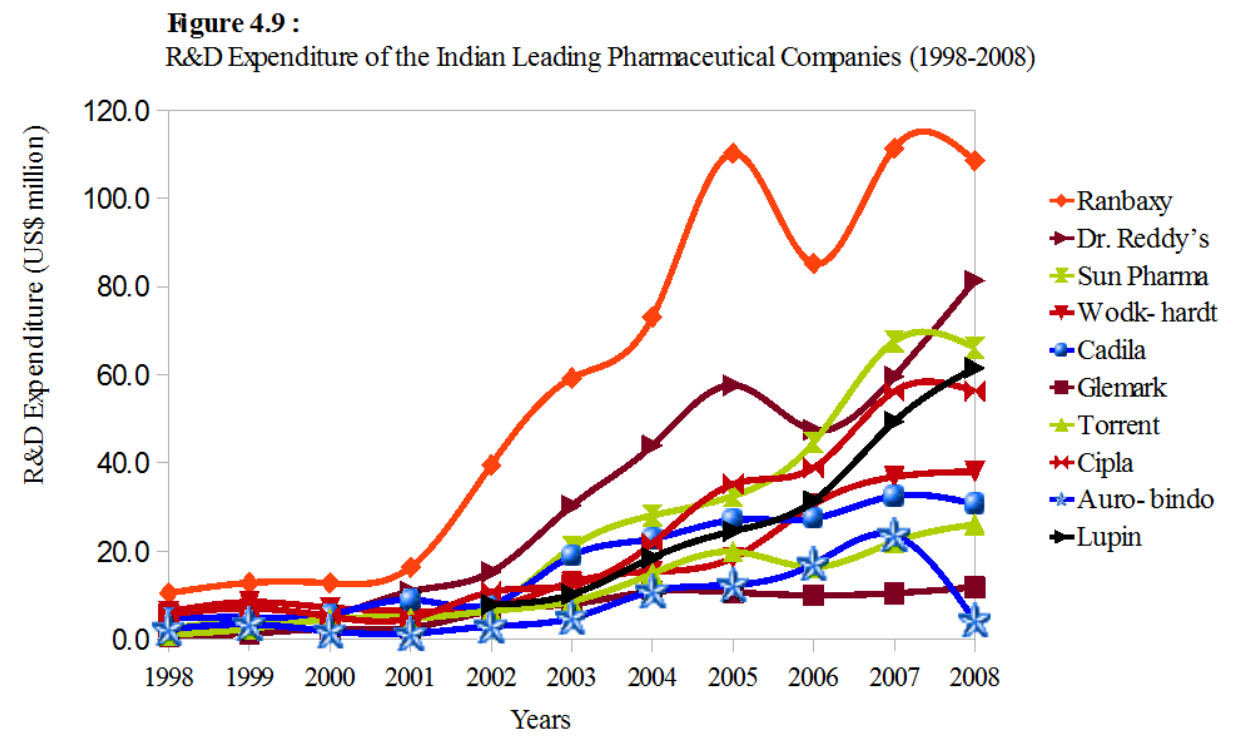

Companies together spent US\$484.1 million on R\&D including new drug development. But, the share of top ten leading pharmaceutical companies spent on new drug development is an amount which is less than on half of what it costs to develop a single new drug abroad (US\$847 million). Another reason that forced Indian companies to enhance their R\&D efforts and investment is changes in patent law under TRIPs obligation preventing the reverse engineering of patent molecules. Consequently moving the value chain of R\&D during pre TRIPs period from process development account 65\%, NDDS accounts $39 \%$ and NCEs accounts 5\% to $35 \%, 35 \%$ and $30 \%$ respectively during post TRIPs era.

Though, spending on R\&D in relation to the GDP in India has increased over the years the difference between spending in $R \& D$ between India and the developed countries still remains considerably high. India spends approximately $0.88 \%$ of its GDP on R\&D which is quite low compared to countries like China ( $1.4 \%$ of GDP) and most developed countries spending more than $2 \%$ of their GDP (Patnaik et al, 2009). As Ernst and Young estimated R\&D expenditure as a percentage of sales in India was $1.4 \%$ in 2001 which has increased $9.9 \%$ in the year 2008. It is important to note that during 1995 to $2008 \mathrm{R} \& \mathrm{D}$ expenditure for domestic companies (29.8\%) performing well as compared to foreign firms (21.4\%) (Table 6). Foreign firms doing well after TRIPs period. It is further indicated that R\&D intensity in India has improved over the period of time particularly during post TRIPS era. 
Table-6: Trends of R\&D Expenditure in India Pharmaceutical Industry

\begin{tabular}{|l||r||r||r|r|r|}
\hline \multicolumn{1}{|c|}{ Year } & $\begin{array}{c}\text { Domestic R\&D } \\
\text { Exp. }\end{array}$ & $\begin{array}{c}\text { Foreign R\&D } \\
\text { Exp. }\end{array}$ & Total R\&D Exp. & Growth rate (\%) & R\&D Intensity \\
\hline $1990-91$ & - & - & 34.6 & - & NA \\
\hline $1991-92$ & - & - & 35.5 & 2.6 & 0.01 \\
\hline $1992-93$ & - & - & 36.8 & 3.7 & 0.01 \\
\hline $1993-94$ & - & - & 39.8 & 8.2 & 0.01 \\
\hline $1994-95$ & - & - & 44.7 & 12.3 & 0.01 \\
\hline $1995-96$ & 24.9 & 19.8 & 44.7 & 0.0 & 0.01 \\
\hline $1996-97$ & 40.3 & 23.6 & 63.9 & 43.0 & 0.02 \\
\hline $1997-98$ & 40.8 & 24.6 & 65.4 & 2.3 & 0.01 \\
\hline $1998-99$ & 37.3 & 21.9 & 59.2 & -9.5 & 0.01 \\
\hline $1999-00$ & 50.7 & 18.5 & 69.2 & 16.9 & 0.01 \\
\hline $2000-01$ & 57.2 & 20.1 & 77.3 & 11.7 & 0.01 \\
\hline $2001-02$ & 92.2 & 23.3 & 115.5 & 49.4 & 0.02 \\
\hline $2002-03$ & 123 & 22.6 & 145.6 & 26.1 & 0.02 \\
\hline $2003-04$ & 147.4 & 49.9 & 197.3 & 35.5 & 0.02 \\
\hline $2004-05$ & 239.4 & 76.5 & 315.9 & 60.1 & 0.03 \\
\hline $2005-06$ & 346.3 & 115.8 & 462.1 & 46.3 & 0.04 \\
\hline $2006-07$ & 408.6 & 180.1 & 588.7 & 27.4 & 0.04 \\
\hline $2007-08$ & 574.3 & 168.4 & 742.7 & 26.2 & 0.04 \\
\hline $2008-09$ & 638.9 & 161.3 & 800.2 & 7.7 & 0.05 \\
\hline
\end{tabular}

Note: During 1990-1994 do not find separate data for domestic \& foreign expenditure.

Source: Compiled from Indiastat database \& Bulk Drug Manufacturers Association India

Note: R\&D Intensity defined as the ratio of expenditures by a firm on R\&D to the firm's sales (NetSales).

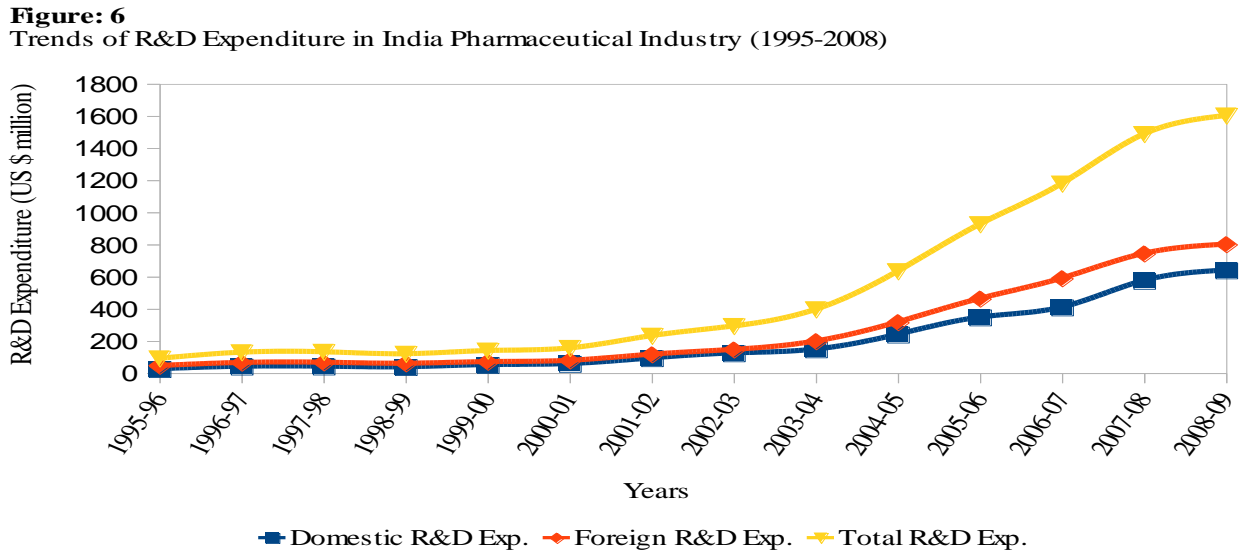

\section{New Chemical Entities (Nces)}

New chemical entities is an expensive time consuming and risky business, as 10,000 molecules enter the drug discovery stage but only one drug approved for marketing. There are many NCEs which are at different stages of development. The largest spenders are Dr. Reddy's and Nicholas Piramal, Ranbaxy. Some of these have successfully completed pre-clinical trial and are at different stages of clinical trials.

According to H. Kajaria (Executive director of Pharma KPMG) Indian Pharmaceutical companies will spend \$ 500 million in the year 2010 on NCE research and \$ 1.2 billion by 2015 .

Dr. Reddy's has 4 molecules in its NCE pipeline in 2008. Similarly Sun pharma, Nicholas Piramal, Wockhardt, Ranbaxy ZydusCadila and Lupin have four, thirteen, five, seven, four and four respectively Recently Ranbaxy launched India's first new drug, Synriam ${ }^{\mathrm{TM}}$, for the treatment of uncomplicated Plasmodium falciparum malaria, in adults.

It is important to note that none of these companies is engaged in the entire process of drug development because they do not have all the skills and fund required. 


\section{Abbreviated New Drug Applications (Andas)}

For marketing a formulation to USA, Indian companies are required to file an ANDA. When a company files an ANDA it is required to mention the suppliers of the bulk drugs and DMF numbers. This is an expensive and time consuming process and the approval may take up to five years. Of the total ANDAs approved in the USA, $30 \%$ of is Indian making the second place next to USA. Various other agencies like Medicines control healthcare products regulatory agency (MHRA) U.K, Therapeutic Goods Administration (TGA) Australia and Health Promotion Board (HPB) Canada are also being filed from India. There are 132 (29\%) ANDAs approved during 2007-08 followed by Israel 40 (9\%) Germany 25 (5\%), Canada 24 (5\%) and others (Table 7A). As far as domestic companies are concerned in the year 2008 Ranbaxy submitted 6 ANDAs in the USA and has the largest basket of products in the US market with 142 approved drugs and another 98 application were pending for approved (Annual Report 2008). It is followed by Dr. Reddy's (70), Sun Pharma (53), Wockhardt (23), Cadila (34), Glanmark (40) and Aurobindo (67), (Table 7B).

Table- 7(A):Country-wise ANDAs Approvals (2007-08).

\section{Source:}

\begin{tabular}{|c|c|c|}
\hline Country & In Number & Share \% \\
\hline USA & 169 & 38 \\
\hline India & 132 & 29 \\
\hline Israel & 40 & 9 \\
\hline Germany & 25 & 5 \\
\hline Canada & 24 & 5 \\
\hline Switzerland & 19 & 4 \\
\hline Iceland & 14 & 3 \\
\hline Jordan & 11 & 2 \\
\hline China & NA & NA \\
\hline Others & 25 & 5 \\
\hline
\end{tabular}

Compiled from Department of Pharmaceutical, Annual Report 2009-10, Government of India, New Delhi.

\footnotetext{
Figure: 7(A)

Country-wise ANDAs Approvals (2007-08)
}

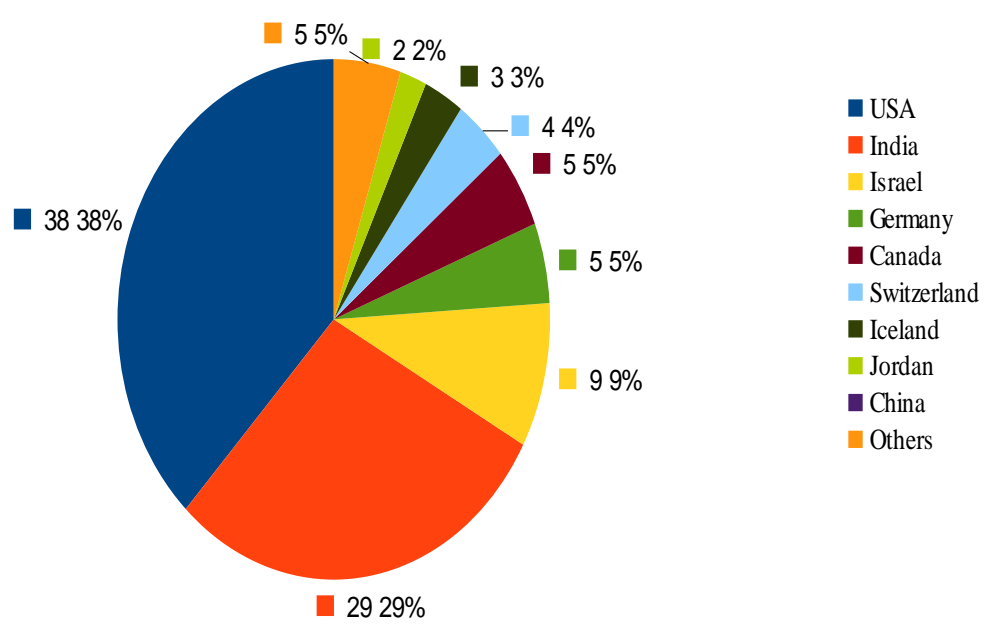

Table- 7(B): Company-wise ANDAs filing from India as upto 2008(In numbers)

\begin{tabular}{|c|c|c|}
\hline Company & $\begin{array}{c}\text { ANDAs filing as on } \\
\text { 31 March 2008 }\end{array}$ & $\begin{array}{c}\text { ANDA Approvals as on 31 } \\
\text { March 2008 }\end{array}$ \\
\hline Ranbaxy & 241 & 142 \\
\hline Dr. Reddy's & 122 & 70 \\
\hline Sun PharmaIndus & 142 & 53 \\
\hline Wockhardt & 57 & 23 \\
\hline Cadila Healthcare & 81 & 34 \\
\hline Glenmark & 51 & 40 \\
\hline Torrent & 11 & 4 \\
\hline Aurobindo & 128 & 67 \\
\hline Lupin & 90 & 34 \\
\hline Cipla & NA & NA \\
\hline
\end{tabular}

Source: Compiled from Annual Report of Respected Companies. 
Figure: 7(B)

Company-wise ANDAs filing from India as upto 2008 (\%)

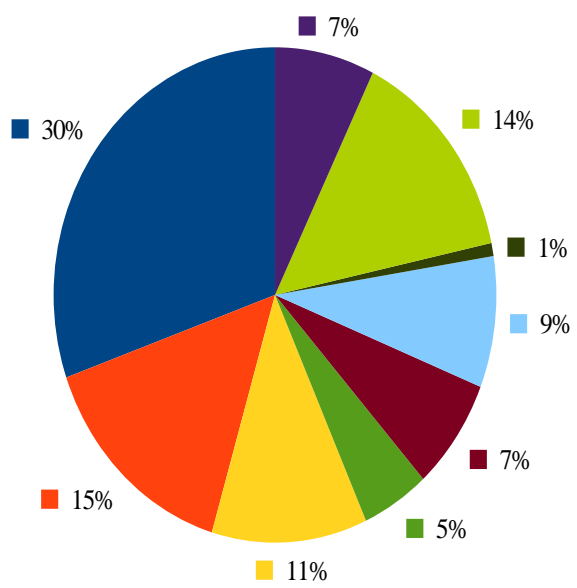

- Ranbaxy

Dr. Reddy's

Sun PharmaIndus

Wockhardt

- Cadila Healthcare

- Glenmark

- Torrent

Aurobindo

- Lupin

Cipla

VI. Drug Master Files (Dmfs)

For exporting bulk drugs to USA, Indian manufacturers are required to file a DMF. The company filing a DMF is required to submit confidential detailed information on kind of equipment, location of the plant, description of production facility process chemistry, raw materials specification, stability data, impurity profit and so on. The cost of filing a DMF can be estimated to be US $\$ 200,000$ depending on the product (the steps involved in the processes the number of test to be done etc) (Chaudhuri, 2005). One-third of all DMFs with USFDA come out of Indian facilities. Now India has the highest number of FDA approved Plants (119) in addition to 84, MHRA approved plant in UK. Recently, 1735 (31\%) DMFs filed by India which higher than Spain Italy, China and Israel put together followed by USA (20\%), Italy (13\%), and Others (Table 8A). Company wise Dr. Reddy's has the largest DMFs (55) in the year 2008 (Table 8B).

Table-8 (A):Country-wise DMFs Filed with USFDA (2008)

\begin{tabular}{|c|c|c|}
\hline Country & In Number & Share \% \\
\hline India & 1735 & 31 \\
\hline USA & 1054 & 20 \\
\hline Italy & 679 & 13 \\
\hline China & 563 & 10 \\
\hline Japan & 311 & 6 \\
\hline Germany & 286 & 5 \\
\hline Spain & 248 & 5 \\
\hline France & 200 & 4 \\
\hline Switzerland & 163 & 3 \\
\hline Israel & 162 & 3 \\
\hline
\end{tabular}

Source: Compiled from, Annual Report 2009-10, Department of Pharmaceutical, Government of India.

Figure: 8(A)

Country-wise DMFs Filed with USFDA (2008)

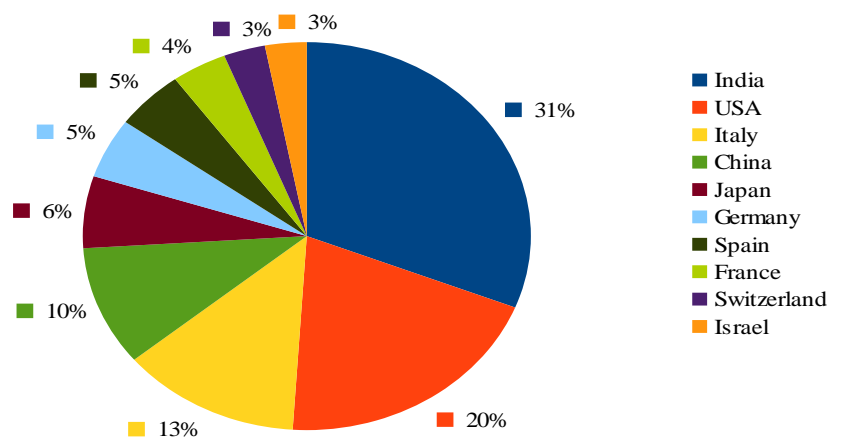

Table- 8 (B): Company-wise DMFs Filed from India as upto 2008 
In numbers

\begin{tabular}{|c|c|c|}
\hline Company & $\begin{array}{c}\text { DMF Filing with USFDA as on } \\
\text { 31 March 2008 }\end{array}$ & $\begin{array}{c}\text { Global DMF filings as on 31 } \\
\text { March 2008 }\end{array}$ \\
\hline Ranbaxy & NA & 271 \\
\hline Dr. Reddy's & 127 & 281 \\
\hline Sun Pharmaceutical & NA & 101 \\
\hline Wockhardt & 8 & NA \\
\hline Cadila Healthcare & 59 & NA \\
\hline Glenmark & 30 & 37 \\
\hline Torrent & 6 & 23 \\
\hline Aurobindo & 122 & 1017 \\
\hline Lupin & NA & NA \\
\hline Cipla & $87^{\#}$ & NA \\
\hline
\end{tabular}

Source: Compiled from, Annual Report of Respected Companies \# 0n December 2007

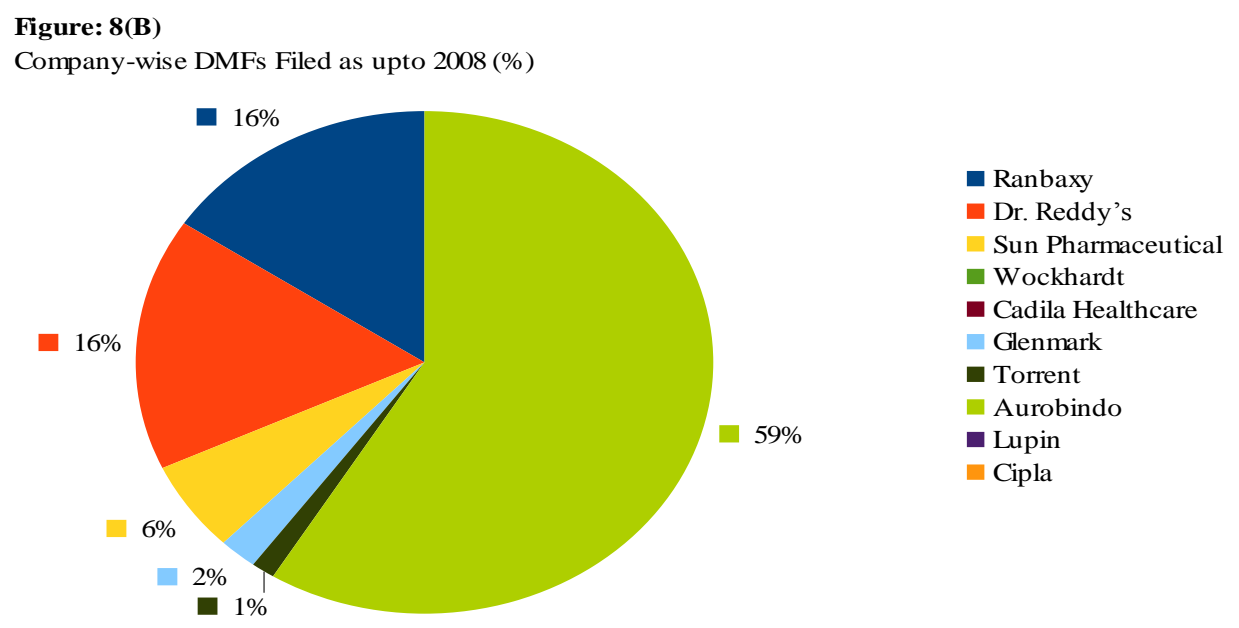

VII. Patent Protection

The principal economic rationale for granting patent is that it will stimulate investment for research and innovation. Patent protection is considered to be important in the pharmaceutical sector because, the costs of developing a new drug are high and the costs of developing process for manufacturing a new drug are low (Grabowski 2002). Till the early 1970s India essentially has a product patent regime in pharmaceutical. It was abolished in 1972 (Patent Act 1970). Many economists argued that Indian patent Act 1970 was crucial in the growth of the Indian pharmaceutical sector because it gave space to Indian companies to develop alternate process which they did so successfully.

After establishment of WTO, TRIPs came in to force on January $1^{\text {st }}, 1995$, with introduction of full product patent protection in all fields including pharmaceutical from January $1^{\text {st }}, 2005$. After TRIPs, India had to introduce product patent by January $1^{\text {st }}, 2005$. The term of patents is now 20 years. All the product patent applications held in the mail box are also required to be taken up for examination from January 1, 2005. Currently a total of 35218 patent applications were in field out of which 6040 (17\%) are from domestic companies and 29178 from foreign applicants (Economic times, 2009) Dr. Reddy filed the largest number of patent applications (147) followed by Ranbaxy (101), Avesthagen Ltd., (66) and others (Table 9).

Table-9: Top Ten Indian Applicants for Patents from Pharmaceutical Sector (2008).

\begin{tabular}{|l|c|}
\hline \multicolumn{1}{|c|}{ Company } & Application Filed in Number \\
\hline Dr. Reddy's & 147 \\
\hline Ranbaxy & 101 \\
\hline Avesthagen Ltd. & 66 \\
\hline Cadila Healthcare Ltd & 57 \\
\hline Matrix Laboratories Ltd & 54 \\
\hline Orchid Chemical \& Pharmaceutical Ltd & 22 \\
\hline AurobindoPharma & 22 \\
\hline Jubilant Organosys Ltd & 21 \\
\hline Ind Swift Laboratories Ltd & 19 \\
\hline Panacea Biotech Ltd. & 15 \\
\hline
\end{tabular}

Source: Compiled from, Annual Report (2008-09), Office of Controller General of Patents, Designs, Trademarks and Geographical Indication. Government of India, New Delhi. 
Figure: 9

Top Ten Indian Applicants for Patents from Pharmaceutical Sector (2008)

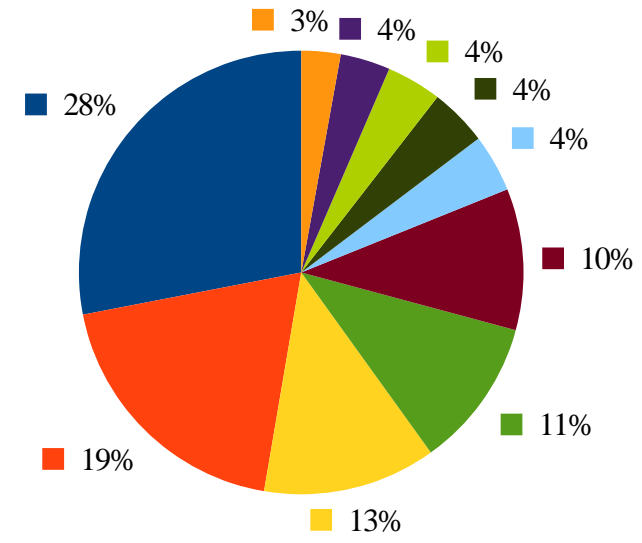

Dr. Reddy's

Ranbaxy

Avesthagen Ltd.

- Cadila Healthcare Ltd

- Matrix Laboratories Ltd
Orchid Chemical \& Pharmaceutical Ltd

- AurobindoPharma

Jubilant Organosys Ltd

Ind Swift Laboratories Ltd

\section{Contract Research And Manufacturing Services (Crams)}

Recently contract manufacturing has emerged as a new growth strategy for many Indian pharmaceutical companies, by offering contract services like marketing, research, clinical trials, data management and laboratory services to global pharmaceutical companies. The process of out-sourcing brings substantial economic gains to global firms as they contracts the production of their products to those who can work cost effectively and qualitatively and thus relieve them to focus on their core competencies and high valueadded operations like research and marketing. For Indian firms out-sourcing not only provide additional sources of revenues, but also access to new technologies, marketing networks and best business practices abroad.

Important reason for CRAMS for sweeping across the sectors is severe cost pressure of global market. India is the fastest growing custom manufacturing out sourcing destination with a growth rate of $43 \%$, which is thrice of the global market rate. The pharmaceutical industry is increasingly facing cost pressures due to rising manpower cost, higher regulatory risk and R\&D productivity of these players has gone down significantly in recent years. In addition, the process of getting approval for new products in regulated markets requires strict compliance of quality norms, which is stringent and is also subject to high legal risk. It is causing MNCs to outsource part of their R\&D and manufacturing activities to low cost destinations like India. About a third of total $R \& D$ investment by the global pharmaceutical industry, estimated at $\$ 40$ - $\$ 50$ billion, could be made in India over the next 10 years.

India is emerging as the global hubs for CRAMS not only due to its low cost advantage and world class quality standards as per the GMP norms. The diverse disease profile and abundance of patient in the country provides better ground for clinical trials. India has leveraged this advantage to attract clinical trials process out sourced by the companies involved in innovation. Nicholas piramal, Sharun Chemicals, Devis Lab, Dishman Pharma, Cadila Healthcare, Lupin and Aurobindo Pharma are some of the companies which have witnessed impressive growth in revenues from their CRAMs business. Consequently, India's share of the global out sourcing market is expected to grow from 2.2\% in 2008 to 3.5\% in 2010 (Express Pharma, 2010).

Further, India is among the fastest growing clinical research destinations, with a growth rate two and half times the overall market growth rate. The country also participate in $7 \%$ of global phase III and $3.2 \%$ of phase II trials with industry sponsored trials demonstrating a CAGR of 39\% between 2004-08 (Ernst \&Yong,2010)

\section{Employment In Indian Pharmaceutical Industry}

In the last decade the pharmaceutical industry has grown by about 12-15\% CAGR. The rapid expansion of pharmaceutical sector has opened up several job opportunities. As per KMPG (2006) pharmaceutical industry employs 29 million people (5 million direct and 24 million indirect). It is indicates that pharmaceutical employment increased nearly twice since 1995 and growing with 4\% CAGR (Table 10). In major Indian states like Maharashtra, Gujarat and Andhra Pradesh this sector employees the largest number people. The ministry of pharmaceutical has estimated that this sector has created around 2.2 million employment opportunities. Besides this the industry offers great employment opportunities on research and other skilled workers due to the factors 
like increasing out-sourcing and expansion of the sector. The concept of pharma retail chain that has gained momentum in the recent years has also created numerous employment opportunities.

Table-10: Employment in Indian pharmaceutical industry (1995-2008).

\begin{tabular}{|r|r|r|}
\hline Years & No. of Employees in Pharma sector & Growth Rate (\%) \\
\hline 1995 & 181497 & 12.7 \\
\hline 1996 & 204609 & 3.4 \\
\hline 1997 & 211614 & -10.5 \\
\hline 1998 & 189295 & 13.1 \\
\hline 1999 & 213999 & 13.7 \\
\hline 2000 & 243410 & -4.0 \\
\hline 2001 & 233704 & -3.1 \\
\hline 2002 & 226416 & -1.3 \\
\hline 2003 & 223556 & 7.7 \\
\hline 2004 & 240791 & 10.2 \\
\hline 2005 & 265396 & 9.3 \\
\hline 2006 & 290021 & 15.9 \\
\hline 2007 & 336211 & 5.2 \\
\hline 2008 & 353692 & \\
\hline
\end{tabular}

Source: Bulk Drug Manufacturers association in India, Hyderabad.

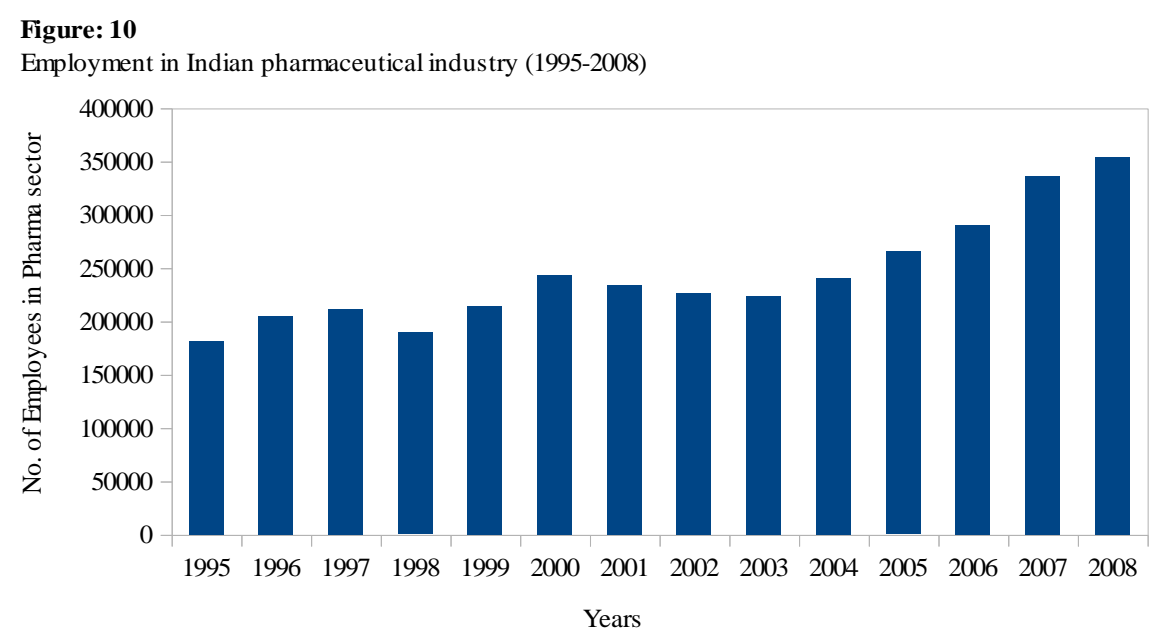

X. Indian Pharmaceutical Industry In Global Market

The global market for pharmaceutical industry has shown tremendous growth over the past decade. But the geographic spread of this growth has been very uneven. Large markets in the world are USA (45\%), Europe (24\%) and Japan (11\%). China contributed 2\% and India's contribution was a meager 1.8\% (Priolkar, 2009).

The Indian industry is highly fragmented with no firm controlling more than $7 \%$ of the market (ICRA, 2004). The top ten companies in India hold approximately $37 \%$ of the market, which is lower than the global structure of $44 \%$. IPI has been consistent growing at a 12-15\% (CAGR) as against global average of $4-7 \%$ during 2008-13. One of the unique features of Indian pharmaceutical market is that it has dominated branded generic (86\%) and rest (14\%) generic-generic drugs market (Yes Bank Report, 2009). India accounts for 22\% of global generic market. Top global generic players in 2007 were Teva ( $\$ 9.1$ billion), Sandoz (\$5.8 billion), Mylan (\$4.6 billion) and Watson (\$2.7 billion). Together they accounted for 47\% of the US market in 2009. As compared to these foreign companies Ranbaxy share was $\$ 1.7$ billion, Dr. Reddy's $\$ 1.7$ billion and Wockhardt 0.4 billion (DOP, 2009-10).

India has 793 WHO cGMP (Current Good Manufacturing Practices) approved Pharmaceutical Plants (DOP, 2009-10). Further India has the highest number of USFDA approved plant (119 plants) outside the US. India accounts for over $1 / 3^{\text {rd }}$ of Drug master files and $30 \%$ of all approved ANDAs in the US placing it at the second position next only to USA. Even in patent challenges India ranks next to USA with a share of $21 \%$ of patent challenges. The country also stands at 3rd position in terms of volume of production (10\% of global share) and $14^{\text {th }}$ in terms of value $(1.5 \%)$. Besides this India has $2 \%$ of the world pharmaceutical market (DOP, 2009). However, there is a vast gap in the amount of pharmaceutical R\&D expenses undertaken by foreign companies (15-20\%) and the Indian companies (5-8\%).

It is heartening to observe that India has increased its pharmaceutical exports at a rapid pace since the 1990s. Our trade balance increased to $\$ 200$ million in 1990 to $\$ 4.3$ billion in 2008 . India is top $17^{\text {th }}$ net exporter 
in the world. However, irrespective of its impressive export growth rates, India's share in the global pharmaceutical exports has not shown much improvement. It is hovering around 1\%. Further, as per WHO study India accounts nearly $1 / 3^{\text {rd }}$ of world's spurious drugs market. Similarly if we compare our per capita drug expenditure to other developed countries it is quite low i.e. \$3 while in USA it is \$222.

\section{Issues Arising Out Of Wto Regime}

The WTO was established on January 1, 1995 and is responsible for making and enforcing rules for trade between nations. Apart from goods the two other broad areas that WTO covers are services and intellectual property, which previously belonged to the domestic domain. Accordingly, WTO administers not only the Multilateral Trade Agreement (MTA) in goods but also the General Agreement on Trade in Services (GATS) and the Agreement on Trade Related Aspects of Intellectual Property Rights (TRIPs) which came into existence with WTO. Therefore, the TRIPs agreement was born to protect the interests of the industry trade and services. India was a signatory member to the TRIPs agreement.

Certain issues and developments arising out of WTO regime, pose a major challenge to our manufacturers. Due to TRIPs with GMP compliances schedule M compliance was made mandatory. As GMP is considered as the bench mark of product quality, it is important not only for maintaining market share in domestic market but also for accessing extremely competitive expert markets. As financial constraints hindering the small firms for adopting GMP criteria as a result $9 \%$ of SSIs were unable to comply with it and $8 \%$ were closed. (Iyear, 2008). It adversely affects the production of bulk drugs and level of employment.

\section{CONCLUSION}

Pharmaceutical industry contributes to the welfare of humanity and provides significant socioeconomic benefits to the society through creation of jobs, supply chains and community development. The industry also plays an important role in technological innovation, which may reduce costs of economic activity elsewhere in the economy. IPI is one of the world's largest and most developed, ranking fourth in terms of volume and thirteenth in terms of value. The country accounts for an estimated $10 \%$ of global production and $2 \%$ of world markets in pharmaceuticals. It has over the years made significant progress in infrastructure development, technical capability and hence produced a wide range of pharmaceutical products. The industry now produces bulk drugs under all major therapeutic groups. It has a sizable technically skilled manpower with prowess in process development and downstream processing. It has the capital investment of about US $\$ 4.1$ billion. It produced bulk drugs of value of US $\$ 3.5$ billion and formulations worth US\$15.4billion in 2008. Bulk drugs have grown at a rate of approximately $14 \%$, and formulation by $24 \%$ in the nineties. There is an increasing interest and investment in R\&D. It provides employments 29 million people. The contribution of pharmaceutical sector in India's GDP is $2 \%$ and $12 \%$ of manufacturing sector GDP.

Presently, $70 \%$ of requirement of the country in bulk drugs and almost all the demands for formulations are met by the domestic industry. In addition to catering to the needs of the domestic demand it is also the leading supplier of bulk drugs and cheap formulations to the world and engaged in contract manufacturing contract research, clinical trials, contracts R\&D. Huge population with a large growing middle class, low cost of production but high quality standard and existence of good infrastructure are the main strengths of Indian pharmaceutical. China is being touted as the biggest threat to the IPI, but large opportunities exist for Indian companies internationally as many Indian drug manufacturing facilities conform to international quality certificates like USFDA, UK MCA.

\section{References}

[1]. Budget (2007-08). Ministry of finance, Government of India, New Delhi www.india.budget.nic.in.

[2]. Cadila Annual Report (2008 \& 2009). www.zyduscadila.com

[3]. Chaudhuri S. (2005). "The WTO and India's Pharmaceutical Industry; patent protection, TRIPs and Development Counties", Oxford University Press, New Delhi: 45-188.

[4]. Department of Pharmaceutical (2009), Ministry of Chemical and fertilizers, Government of India, New Delhi, www. pharma.nic.in.

[5]. DiMasi J.A., R.W. Hansen, and H.G. Grabowski, "The Price Innovation: New Estimates of Drug Development Costs.” Journal of Health Economics 2003, 22(2):151-85.

[6]. Directory of pharmaceutical manufacturing units in India (2007), National Pharmaceutical Pricing Authority, Government of India, New Delhi. http://www.nppaindia.nic.in.

[7]. Dr. Reddy's Annual Report (2009). www.drreddys.com

[8]. Ernst \& Young (2010). "Doing Business in India”, Ernst \&Yong Pvt Ltd, Kolkata, www.ey.com/india: 45-46

[9]. Expert - Import Bank of India (2007). "Indian Pharmaceutical Industry, Surging Globally", Occasional Paper No. 119, Quest Publication August: p.28.

[10]. Express Pharma (2007): "Shaping SEZ", 16-31 December, Fortnightly insight for pharma professionals. www.expresspharmaonline.com.

[11]. Express Pharma (2010a). "Strategic Partners in Prosperity: All CRAM Med up" Fortnightly insight for Pharma Professionals, 16-31 July.www.expresspharma.online.com.

[12]. Grabowski Henry (2002). "Patents, Innovation and Access to New Medicines", Journal of International Economic Law, 5(4), December. 
[13]. IBEF (2008), "Pharmaceuticals: December, 2008”, Indian Brand Equity Foundation (www.ibef.org).

[14]. IBEF (2010)."Pharmaceuticals", April 2010, Indian Brand Equity Foundation. www.ibef.org.

[15]. ICRA Ltd. (2004)."Industry Watch: The Indian Pharmaceutical Industry", Information and credit Rating Agency, New Delhi.

[16]. Iyer Parvathi. K. (2008). "Structure and Performance of Small and Medium Scale Pharmaceutical Firms", S\&T and Industry, India, Science and Technology:11

[17]. Jha Ravinder (2007). "Options for Indian Pharmaceutical Industry in the Changing Environment”, Economic and Political Weekly, Sameeksha Trust Publication, XLII (39): 3958-3967: 3959, Mumbai.

[18]. Mashelkar Committee (2003). "Report of the Export Committee on a comprehensive examination of Drug Regulatory Issues, Including the problem of spurious drugs", New Delhi, Government of India, Ministry of Health and Family Welfare, Para 6.3.4:3

[19]. National Pharmaceutical Policy (2006), Department of Chemical and Petrochemicals, Government of India, December 28, 2005, Part A.

[20]. Pharmaxil (2009), $6^{\text {th }}$ Annual Report, 2009-10: 8.

[21]. Piramal Healthcare Annual Report (2006). www.piramal healthcare.com.

[22]. Priolkar Subodh (2009). "Can India be Pharmaceutical Superpower in 2020?” Pharma Times, 41(1), January.

[23]. Ranbaxy Annual Report (2007 \& 2008), www.ranbaxy.com.

[24]. Report (2006). "Impact of TRIPs on pharmaceutical price: with Specific focus on generics in India", NIPER, Project under the work plan of the WHO Biennium 2004-05 and ministry of Health and family welfare, Government of India, 22 April.

[25]. Roumeliotis Gregouy (2006). "India geared up for unprecedented manufacturing growth", In Pharma Technology.com, 15 August.

[26]. Sun Pharma Annual Report (2007-08), www.sunpharma.com.

[27]. Wockhardt Annual Report (2007\&2009). www.wockhardt.com. 